\section{STRATEGI EMPOWERMENT} PADA LINGKUNGAN KERJA KEPERAWATAN

\section{Oleh : Ns. Rizeki Dwi Fibriansari, M.Kep}

Pemberdayaan atau empowerment menjadi sesuatu hal yang penting karena didalam menghadapi era persaingan dan pelayanan keperawatan dibutuhkan perawat yang cepat, tanggap dan mandiri. Empowerment perawat di rumah sakit akan memberikan dampak positif terhadap kepuasan kerja, kepuasan pasien, dan organisasi. Selain itu, hal ini dapat menambah inisiatif pribadi perawat dengan mampu menumbuhkan rasa kepemilikan secara psikologis. Pengembangan model empowerment mampu meningkatkan tanggung jawab dan kemandirian perawat pelaksananya melalui koordinasi dan controling secara berkala dengan rapat dan supervisi keperawatan. Strategi empowerment pada perawat dapat diaplikasikan di tatanan pelayanan kesehatan untuk membuat kebijakan bagi rumah sakit mengenai tugas pokok dan fungsi perawat, jenjang karir perawat, pemberian reward sebagai motivasi perawat bekerja lebih profesional sehingga menurunkan tingkat kelelahan perawat dan meningkatkan kualitas kerja perawat.

\section{RIZEKI DWI FIBRIANSARI}

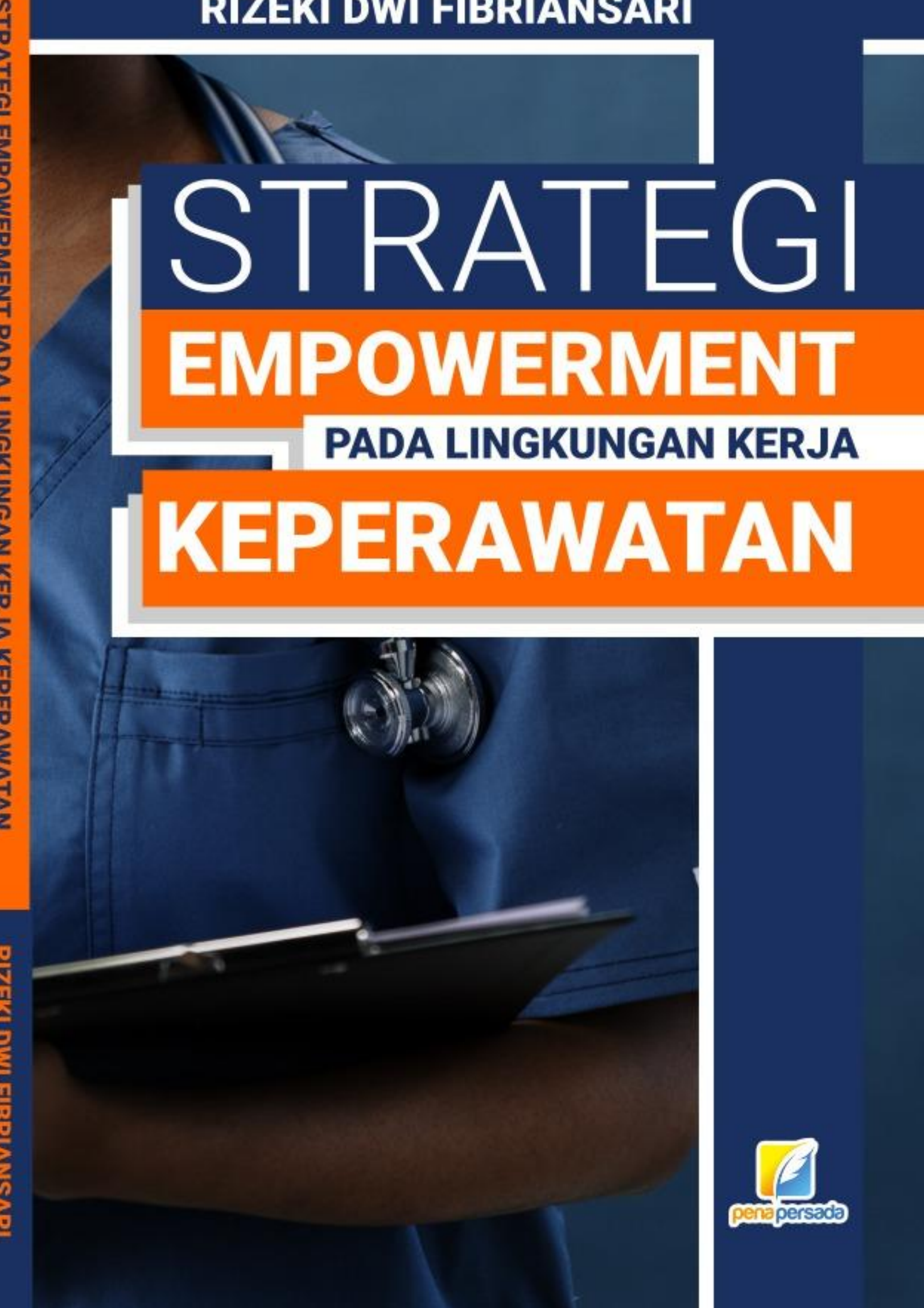




\section{STRATEGI EMPOWERMENT \\ PADA LINGKUNGAN KERJA KEPERAWATAN}

Rizeki Dwi Fibriansari

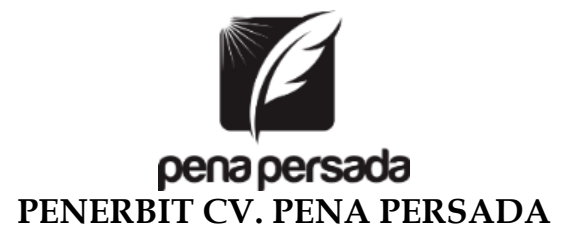




\title{
STRATEGI EMPOWERMENT \\ PADA LINGKUNGAN KERJA KEPERAWATAN
}

\author{
Penulis: \\ Rizeki Dwi Fibriansari \\ ISBN: 978-623-315-339-3 \\ Editor: \\ Wiwit Kurniawan \\ Design Cover: \\ Retnani Nur Briliant
}

\section{Layout:}

Nisa Falahia

\section{Penerbit CV. Pena Persada \\ Redaksi:}

Jl. Gerilya No. 292 Purwokerto Selatan, Kab. Banyumas

Jawa Tengah

Email: penerbit.penapersada@gmail.com

Website: penapersada.com Phone: (0281) 7771388

Anggota IKAPI

All right reserved

Cetakan pertama: 2021

Hak Cipta dilindungi oleh undang-undang. Dilarang memperbanyak karya tulis ini dalam bentuk apapun tanpa izin penerbit 


\section{KATA PENGANTAR}

Segala puji senantiasa kita panjatkan kehadirat Allah Swt, atas segala rahmat dan karunianya, akhirnya penulis dapat menyelesaikan penyusunan buku yang berjudul "Strategi Empowerment pada Lingkungan Kerja Keperawatan". Saya menyadari bahwa tanpa bantuan dan bimbingan dari berbagai pihak sangatlah sulit bagi saya untuk menyelesaikan karya ini. Oleh karena itu, saya mengucapkan banyak terima kasih pada semua pihak yang telah membantu penyusunan buku ini. Sehingga buku ini bisa hadir di hadapan pembaca.

Dalam buku ini membahas tentang pengembangan model empowerment terhadap burnout syndrome dan quality of nursing work life. Pemberdayaan atau empowerment menjadi sesuatu hal yang penting karena di dalam menghadapi era persaingan dan pelayanan karena dibutuhkan karyawan yang cepat, tanggap dan mandiri sehingga mampu berkompetitif serta memperkuat kapabilitas dan komitmen.

Penulis menyadari bahwa buku ini masih jauh dari kesempurnaan. Oleh karena itu kritik dan saran yang membangun sangat dibutuhkan guna penyempurnaan buku ini. Akhir kata saya berharap Allah Swt berkenan membalas segala kebaikan semua pihak yang telah membantu

Penulis 


\section{DAFTAR ISI}

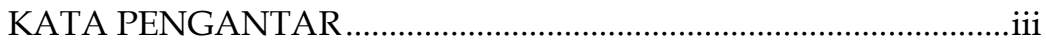

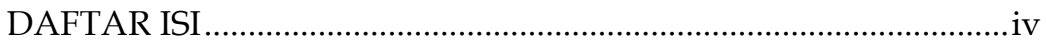

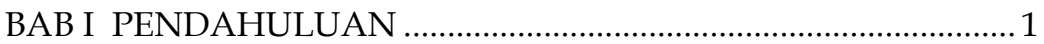

A. Pengembangan Sumber Daya Keperawatan....................... 1

B. Pentingnya Empowerment dalam Kepuasan Kerja ............... 2

BAB II KONSEP RUMAH SAKIT_................................................. 9

A. Definisi Rumah Sakit ...................................................... 9

B. Tujuan Rumah Sakit ......................................................... 9

C. Tugas dan Fungsi Rumah Sakit ......................................... 10

D. Klasifikasi Rumah Sakit .................................................. 11

E. Perawat di Rumah Sakit..................................................... 12

BAB III MANAJEMEN SUMBER DAYA MANUSIA......................... 17

A. Definisi manajemen SDM …………………................... 17

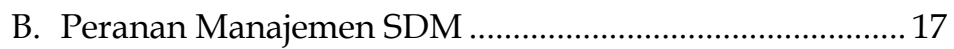

C. Proses Manajemen SDM …….............................................. 18

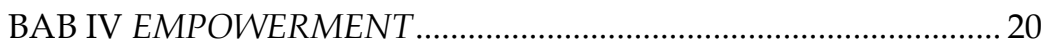

A. Konsep Empowerment ...................................................... 20

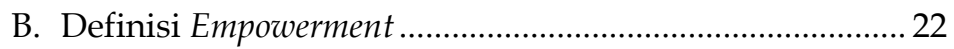

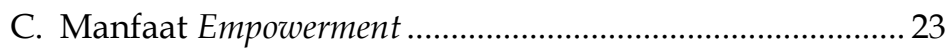

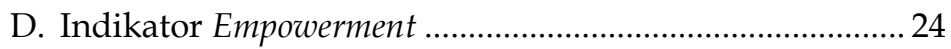

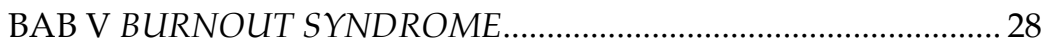

A. Definisi Burnout Syndrome.............................................. 28

B. Faktor-Faktor Penyebab Burnout Syndrome ………….........29

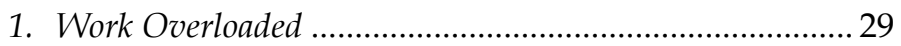

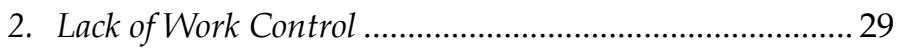

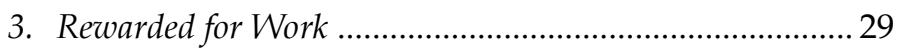

4. Breakdown in Community ................................................. 30

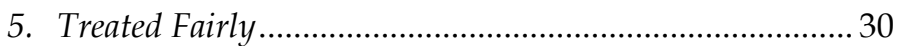

6. Dealing with Conflict Values...............................................30

7. Dimensi Burnout Syndrome ……………………….......... 32

8. Dampak burnout syndrome .................................................. 33

9. Pencegahan Burnout .......................................................... 34

BAB VI QUALITY OF NURSING WORK LIFE (QNWL) ....................36

A. Konsep Quality of Nursing Work Life................................. 36

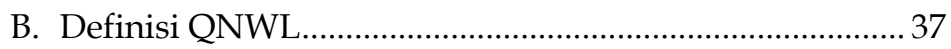


C. Faktor yang mempengaruhi QNWL ……………...............37

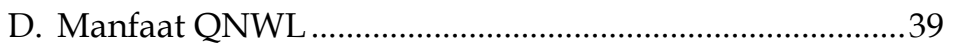

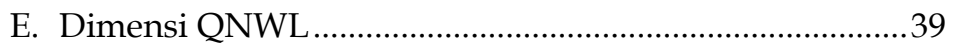

BAB VII IMPLEMENTASI EMPOWERMENT DALAM

MANAJEMEN KEPERAWATAN .........................................42

A. Planning (perencanaan) ……………………….................... 42

B. Organizing (pengorganisasian) ............................................ 43

C. Staffing (Ketenagaan) ………………………….................... 44

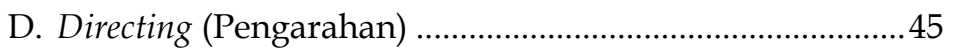

E. Controlling (pengendalian) ..................................................... 46

BAB VIII IMPLEMENTASI JENJANG KARIR PERAWAT DI

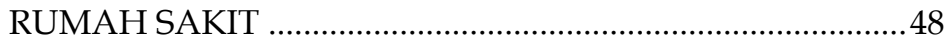

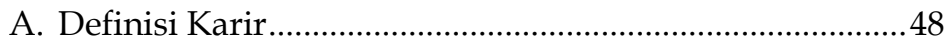

B. Jenjang Karir Perawat ........................................................... 49

BAB IX PENGEMBANGAN MODEL EMPOWERMMET ...............53

A. Structural Empowerment terhadap Psychological

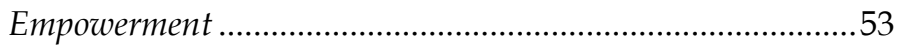

B. Structural Empowerment terhadap Burnout Syndrome ......59

C. Structural Empowerment terhadap Quality of Nursing

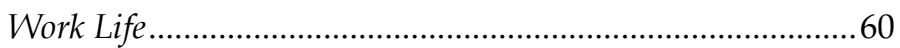

D. Psychological Empowerment terhadap Burnout Syndrome..62

E. Psychological Empowerment terhadap Quality of Nursing

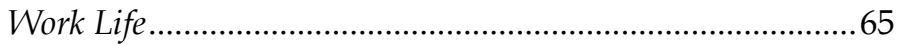

F. Burnout Syndrome terhadap Quality of Nursing Work

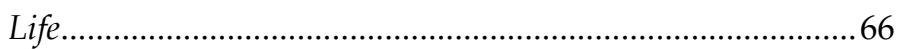

G. Pengembangan Model Empowermmet terhadap Burnout Syndrome dan Quality of Nursing Work Life .........69

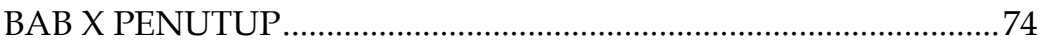

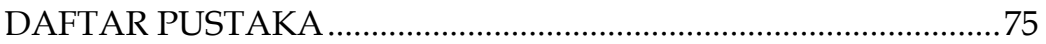

DAFTAR SINGKATAN, ISTILAH DAN LAMBANG ......................81 


\section{STRATEGI EMPOWERMENT \\ PADA LINGKUNGAN KERJA KEPERAWATAN}




\section{BAB I \\ PENDAHULUAN}

\section{A. Pengembangan Sumber Daya Keperawatan}

Sumber daya manusia merupakan salah satu faktor yang sangat penting dalam suatu pelayanan (Hariandja, 2002) dan elemen organisasi yang sangat penting (Salimah, 2009) yaitu menyangkut manusia yang bekerja untuk memberikan usaha atau jasa kerja (Sumarsono, 2003). Sumber daya manusia di rumah sakit terdiri dari berbagai profesi antara lain tenaga kesehatan yang meliputi medis (dokter), paramedis (perawat) dan paramedis non keperawatan serta tenaga non kesehatan yaitu bagian administrasi, personalia dan keuangan (Salimah, 2009). Sumber daya keperawatan merupakan aset dan komponen penting dalam pelayanan rumah sakit yang memiliki kontribusi dalam menentukan citra rumah sakit (Yatnikasari, 2010) dengan jumlah sekitar 55-65\% dari jumlah seluruh karyawan (Hamid, 2007).

Manajemen sumber daya manusia pada hakikatnya merupakan aset utama dan bagian integral dari suatu organisasi maupun perusahaan. Manajemen sumber daya manusia yang strategis memandang bahwa karyawan pada semua bidang pekerjaan dan tingkat apapun adalah baik secara struktural maupun fungsional. Karyawan merupakan salah satu faktor produksi, oleh karena itu harus dimanfaatkan secara maksimal dan produktif (Ahmad, 2014). Pemanfaatan sumber daya manusia sebagai suatu upaya pemberdayaan karyawan di rumah sakit. Pemberdayaan atau empowerment menjadi sesuatu hal yang penting karena di dalam menghadapi era persaingan dan pelayanan, setiap organisasi membutuhkan karyawan yang cepat, tanggap dan mandiri sehingga mampu berkompetitif melalui sumber daya manusia serta memperkuat kapabilitas dan komitmen dari karyawan (Simarmata, 2009). 
Empowerment perawat di rumah sakit akan memberikan dampak positif terhadap kepuasan kerja, kepuasan pasien, dan organisasi, namun masih banyak dijumpai rumah sakit kurang dalam melakukan empowerment kepada karyawannya. Pengembangan sumber daya manusia, khususnya perawat terus dilakukan dengan memberikan kesempatan perawat untuk mengikuti pendidikan berkelanjutan, pelatihan, seminar dan workshop dalam rangka meningkatkan pengetahuan, kompetensi dan ketrampilan. Sebagian besar ruang rawat inap menggunakan MAKP model tim dan setiap ruangan terdiri dari 2-3 tim. MAKP model tim akan memberikan kesempatan kepada ketua tim untuk bertanggung jawab terhadap asuhan keperawatan yang diberikan kepada klien, sehingga anggota tim merasa berkontribusi dan diberdayakan. Di sisi lain dengan rasa tanggung jawab yang diberikan kepada perawat dapat memicu perasaan lelah sehingga mempengaruhi kepuasan kerja perawat. Pengembangan model empowerment pada perawat terhadap burnout syndrome dan quality of nursing work life belum dapat dijelaskan.

\section{B. Pentingnya Empowerment dalam Kepuasan Kerja}

Beberapa data tentang gambaran empowerment perawat di rumah sakit menunjukkan belum efektif. Hal ini ditunjukkan dengan belum ada kesempatan peningkatan karir bagi perawat $(80 \%)$, dukungan dalam kegiatan supervisi belum maksimal menurut supervisor karena struktur organisasi formal yang tidak efektif $(100 \%)$, dan perawat merasa persediaan alat belum memadai $(53 \%)$, sehingga pekerjaan staf dapat terhambat (Jannah, 2011). Data awal empowerment yang didapatkan dari survei kepada 20 perawat disajikan pada tabel 1.1. 
Tabel 1.1 Empowerment Perawat (Desember, 2016)

\begin{tabular}{llccccc}
\hline No. & Kriteria & $\begin{array}{c}\text { Baik } \\
\text { Jumlah }\end{array}$ & \multicolumn{2}{c}{ Cukup } & \multicolumn{2}{c}{ Kurang } \\
Jumlah & $\%$ & Jumlah & \% \\
\hline $\begin{array}{l}\text { Structural } \\
\text { empowerment } \\
\text { (Keterlibatan }\end{array}$ & 6 & 30 & 10 & 50 & 4 & 20 \\
$\begin{array}{l}\text { kerja) } \\
\text { Psychological } \\
\text { empowerment } \\
\text { (Peran kerja) }\end{array}$ & 7 & 40 & 4 & 20 & 9 & 45 \\
\hline
\end{tabular}

Tabel 1.1 menunjukkan structural empowerment yang merupakan keterlibatan perawat dalam bekerja termasuk kriteria cukup sebesar 50\%, sedangkan psychological empowerment yang dapat dilihat melalui peran kerja masih dalam kriteria kurang sebesar $45 \%$. Empowerment perawat di lingkungan kerja akan memberikan kesempatan pertumbuhan kinerja, tetapi ketika kondisi ini kurang maka perawat akan merasa tidak berdaya. Hal ini mengancam produktivitas organisasi karena perawat yang tidak diberdayakan lebih rentan terhadap burnout dan berkurang kepuasan pekerjaan (Laschinger et al., 2004).

Empowerment mengajarkan perawat untuk membuat keputusan dan menerima tanggung jawab terhadap hasil (Simarmata, 2009). Dampak dari empowerment di tempat kerja, atasan dan rekan kerja adalah kepuasan kerja, komitmen organisasi, dan keinginan bertahan (Laschinger et al., 2004). Berdasarkan studi pendahuluan yang dilakukan bahwa 199 perawat dan bidan dari 347 orang (57,3\%) memiliki status kepegawaian sebagai Pegawai Negeri Sipil (PNS) yang disajikan dalam tabel 1.2. 
Tabel 1.2 Jumlah Perawat dan Bidan (Desember, 2016)

\begin{tabular}{|c|c|c|c|c|}
\hline No. & Unit & Ruang & PNS & Kontrak \\
\hline 1. & Manajemen & & 8 & 0 \\
\hline \multirow[t]{10}{*}{2.} & Rawat inap & Alamanda & 7 & 8 \\
\hline & & Aster & 8 & 8 \\
\hline & & Asparaga & 7 & 9 \\
\hline & & Asoka & 7 & 14 \\
\hline & & Melati & 9 & 14 \\
\hline & & Kenanga & 8 & 13 \\
\hline & & Bougenville & 8 & 12 \\
\hline & & Teratai & 10 & 6 \\
\hline & & Perinatologi & 12 & 9 \\
\hline & & VK Bersalin & 14 & 2 \\
\hline \multirow[t]{4}{*}{3.} & Critical care & IGD & 14 & 12 \\
\hline & & ICU & 12 & 7 \\
\hline & & $\mathrm{HCU}$ & 8 & 6 \\
\hline & & Hemodialisa & 12 & 1 \\
\hline \multirow[t]{4}{*}{4.} & Kamar & Bedah Sentral & 15 & 0 \\
\hline & operasi & $\mathrm{RR}$ & 3 & 5 \\
\hline & & Endoscopy & 1 & 1 \\
\hline & & Anastesi & 6 & 2 \\
\hline \multirow[t]{2}{*}{5.} & Rawat Jalan & & 25 & 1 \\
\hline & & Total & 194 & 130 \\
\hline
\end{tabular}

Tabel 1.2 menunjukkan jumlah tenaga PNS perawat sebanyak 164 orang dan bidan 30 orang. Di unit rawat inap jumlah perawat PNS sebanyak 90 orang, unit critical care sebanyak 46 orang, unit kamar operasi sebanyak 25 orang dan unit rawat jalan sebanyak 26 orang. Kurangnya empowerment perawat di rumah sakit berhubungan dengan stres akibat kondisi kerja yang buruk dan penyebab utama kelelahan kerja perawat (Wong, 2007) sehingga dapat menurunkan kepuasan kerja dan meningkatkan risiko burnout (Laschinger et al., 2004). Perawat yang tidak berhasil mengatasi stres kerja akan menyebabkan stres berkepanjangan dan muncul kelelahan emosional, kelelahan fisik, kelelahan mental dan rendahnya 
penghargaan terhadap diri sendiri (Nursalam, 2016). Berdasarkan studi pendahuluan yang dilakukan rasio perawat dengan pasien berkisar $1: 6-7$, hal ini memicu tingginya beban kerja dan kelelahan pada perawat. Survei tingkat kelelahan pada 20 perawat disajikan dalam tabel 1.3.

Tabel 1.3 Tingkat Kelelahan Perawat (Desember, 2016)

\begin{tabular}{clcc}
\hline No. & Tingkat Kelelahan & Jumlah & Prosentase \\
\hline 1. & Tinggi & 8 & $40 \%$ \\
2. & Sedang & 10 & $50 \%$ \\
3. & Rendah & 2 & $10 \%$ \\
\hline & Total & $\mathbf{2 0}$ & $\mathbf{1 0 0} \%$ \\
\hline
\end{tabular}

Tabel 1.3 menunjukkan 10 perawat mengalami kelelahan tingkat sedang. Penyebab kelelahan ini akibat ketidaksesuaian antara jumlah perawat dengan pekerjaan. Hal ini dapat menyebabkan menurunnya kualitas kerja, hubungan yang tidak sehat di lingkungan pekerjaan, menurunkan kreativitas perawat, dan menyebabkan burnout. Perawat juga memberikan pelayanan konstan dan terus menerus kepada pasien, kondisi kerja ini membuat perawat rentan mengalami stres kerja dan keinginan pindah (Hamid, 2007). Hampir $20 \%$ dari perawat yang bekerja lebih dari 40 jam dalam seminggu sebagai faktor penting dalam meningkatkan stress kerja, ketidakpuasan kerja dan kejenuhan (Newman, 2002).

Stres kerja dapat menyebabkan penurunan kinerja (Vecchio, 2008), dampak yang muncul dari penurunan kepuasan kerja dan penurunan komitmen dalam aspek nonpsiklogis berupa perilaku yang diwujudkan oleh karyawan dengan adanya keinginan untuk keluar (Wening, 2005). Kepuasan kerja perawat dapat digunakan untuk menilai quality of nursing work life secara umum. 
Tabel 1.4 Kepuasan Kerja Perawat (Desember, 2016)

\begin{tabular}{llcc}
\hline No. & Kepuasan kerja & Jumlah & Prosentase \\
\hline 1. & Puas & 6 & $30 \%$ \\
2. & Cukup puas & 7 & $35 \%$ \\
3. & Kurang puas & 7 & $35 \%$ \\
\hline & Total & $\mathbf{2 0}$ & $\mathbf{1 0 0} \%$ \\
\hline
\end{tabular}

Tabel 1.4 menunjukkan quality of nursing work life yang secara umum dapat dinilai dari kepuasan kerja perawat dalam kategori cukup dan tidak puas masing-masing sebesar $35 \%$. Hal ini disebabkan beberapa hal, antara lain perawat melakukan pekerjaan administrasi dalam pelayanan terutama saat shift sore dan malam, kebijakan dari atasan mengenai rotasi penempatan kerja sehingga perawat perlu adaptasi kembali dengan lingkungan kerja yang baru dan kurangnya komunikasi efektif dengan tim profesi lain.

Teori Kanter tahun 1976 yaitu "Power in Organizations" menawarkan kerangka kerja yang berguna untuk upaya membimbing pemimpin perawat menciptakan empowerment kerja. Perilaku kerja dan sikap dibentuk dengan menanggapi posisi individu dan keadaan yang timbul dalam organisasi untuk tingkat yang lebih besar sesuai ciri-ciri kepribadian individu. Kemampuan untuk mencapai dan mengatur dukungan, informasi dan sumber daya di tempat kerja berasal dari kedua sistem formal dan informal dalam organisasi (Laschinger et al, 2004). Empowerment pada perawat akan membuat perawat memiliki beban kerja yang wajar, kontrol atas kerja mereka dan hubungan kerja yang baik. Selain itu perawat diperlakukan dengan adil dan dihargai atas kontribusi mereka serta diakui nilai-nilai profesi oleh organisasi (Wong, 2007).

Penelitian Laschinger (2003) menyatakan bahwa persepsi perawat dalam empowerment di tempat kerja secara struktural akan meningkatkan psychological empowerment. Perasaan diberdayakan pada perawat akan menurunkan tingkat burnout. Penelitian selanjutnya yang dilakukan 
Laschinger (2004) untuk mengembangkan teori Kanter menghasilkan teori pemberdayaan organisasi Kanter dalam populasi perawat pendidik di Kanada yaitu tingkat empowerment yang lebih tinggi dikaitkan dengan tingkat kejenuhan yang lebih rendah dan kepuasan kerja yang lebih besar. Penelitian Wong (2007) juga menghasilkan bahwa perilaku empowerment pada pemimpin dapat meningkatkan job fit perawat dan mencegah kelelahan.

Penelitian lain oleh Donahue (2008) bahwa terdapat hubungan yang signifikan antara persepsi empowerment perawat dalam mendapatkan informasi, kesempatan, dukungan dan sumber daya memiliki hubungan positif dengan kepuasan pasien. Penelitian tentang dimensi empowerment didukung juga oleh penelitian yang dilakukan oleh Lina Meng (2015) bahwa pemberdayaan struktural dan pemberdayaan psikologis memiliki efek positif yang signifikan terhadap niat untuk tinggal perawat dan efek negatif pada burnout.

Penelitian Prihastuty (2013) mengemukakan tentang Quality of Nursing Work Life (QNWL) dikategorikan sedang pada work life home life dan work design di RS Premier Surabaya, sedangkan intention to quit dipengaruhi variabel sosial dan administratif. QNWL berpengaruh terhadap intention to quit. Penelitian yang dilakukan Winasih (2015) bahwa kepuasan kerja dipengaruhi faktor lingkungan kerja yang saling berpengaruh terhadap kualitas kehidupan kerja perawat secara profesional dalam lingkungan kerja yang mendukung untuk menciptakan perawat berprestasi, bernilai tinggi, bermanfaat bagi diri sendiri dan berdampak positif bagi produktifitas dan kualitas rumah sakit. Kualitas kehidupan kerja perawat bermanfaat untuk menurunkan ketidakhadiran, penurunan turnover perawat dan peningkatan kepuasan dalam bekerja.

Empowerment dapat menambah inisiatif pribadi perawat karena mereka akan mampu mengidentifikasi dan mengasumsikan rasa kepemilikan psikologis terhadap pekerjaan mereka. Selain itu, empowerment adalah juga untuk menambah motivasi dan produktivitas kerja perawat, sebab 
empowerment sangat membantu meningkatkan partisipasi perawat secara lebih efektif dan membuat segala sesuatu dapat terlaksana dengan baik. Empowerment memiliki efek yang dapat mempengaruhi tingkat burnout. Burnout syndrome terdiri dari tiga komponen yaitu kelelahan emosional, depersonalisasi dan menurunnya prestasi diri (Maslach et al. 2004). Empowerment dapat dikaitkan dengan tingkat kejenuhan dan kepuasan kerja perawat (Laschinger et al 2004). Quality of nursing work life mencakup empat komponen yaitu work life-home life, work design, work context, dan work world (Brooks \& Anderson, 2004).

Peran manajer rumah sakit maupun keperawatan penting sekali untuk memperhatikan dan meningkatkan kualitas kerja dengan pengembangan model empowerment sehingga menurunnya kelelahan fisik maupun mental perawat. Rumah sakit juga dituntut untuk memberdayakan perawatnya semaksimal mungkin agar tercipta kepuasan kerja yang dapat berdampak meningkatnya kinerja perawat yang ada sehingga organisasi dapat kuat dan kompeten (Kusuma, 2007). Strategi empowerment penting untuk meningkatkan keterlibatan dan mengurangi kelelahan di lingkungan kerja keperawatan. Oleh karena itu, manajer keperawatan berperan penting dalam menciptakan lingkungan kerja yang positif sehingga dapat memiliki dampak besar pada perawat menghadapi kondisi kerja dan meningkatkan kualitas pelayanan yang diberikan kepada pelanggan. 


\section{BAB II \\ KONSEP RUMAH SAKIT}

\section{A. Definisi Rumah Sakit}

Menurut Keputusan Menteri Kesehatan Republik Indonesia Nomor 340/MENKES/PER/III/2010 menyatakan bahwa rumah sakit adalah institusi pelayanan kesehatan yang menyelenggarakan pelayanan kesehatan perorangan secara paripurna yang menyediakan pelayanan rawat inap, rawat jalan dan gawat darurat. Sedangkan menurut Undang-Undang Republik Indonesia Nomor 44 Tahun 2009 tentang Rumah Sakit, rumah sakit adalah institusi pelayanan kesehatan bagi masyarakat dengan karakteristik tersendiri yang dipengaruhi oleh perkembangan ilmu pengetahuan kesehatan, kemajuan teknologi, dan kehidupan sosial ekonomi masyarakat yang harus tetap mampu meningkatkan pelayanan yang lebih bermutu dan terjangkau oleh masyarakat agar terwujud derajat kesehatan yang setinggi-tingginya.

Menurut World Health Organization, pengertian rumah sakit adalah suatu bagian dari organisasi medis dan sosial yang mempunyai fungsi untuk memberikan pelayanan kesehatan lengkap kepada masyarakat, baik kuratif maupun preventif pelayanan keluarnya menjangkau keluarga dan lingkungan rumah. Rumah sakit juga merupakan pusat untuk latihan tenaga kesehatan dan penelitian biologi, psikologi, sosial ekonomi dan budaya.

\section{B. Tujuan Rumah Sakit}

Tujuan rumah sakit menurut Undang-Undang Republik Indonesia Nomor 44 Tahun 2009 tentang Rumah Sakit adalah:

1. Mempermudah akses masyarakat untuk mendapatkan pelayanan kesehatan. 
2. Memberikan perlindungan terhadap keselamatan pasien, masyarakat, lingkungan rumah sakit dan sumber daya manusia di rumah sakit.

3. Meningkatkan mutu dan mempertahankan standar pelayanan rumah sakit.

4. Memberikan kepastian hukum kepada pasien, masyarakat, sumber daya manusia rumah sakit, dan Rumah Sakit

\section{Tugas dan Fungsi Rumah Sakit}

Menurut Undang-undang RI No. 44 tahun 2009, rumah sakit mempunyai tugas memberikan pelayanan kesehatan perorangan secara paripurna. Pelayanan kesehatan paripurna adalah pelayanan kesehatan yang meliputi promotif, preventif, kuratif, dan rehabilitatif. Rumah sakit umum mempunyai misi memberikan pelayanan kesehatan yang bermutu dan terjangkau oleh masyarakat dalam rangka meningkatkan derajat kesehatan masyarakat.

Tugas rumah sakit umum adalah melaksanakan upaya pelayanan kesehatan secara berdaya guna dan berhasil guna dengan mengutamakan penyembuhan dan pemulihan yang dilaksanakan secara serasi dan terpadu dengan peningkatan dan pencegahan serta pelaksanaan upaya rujukan. Untuk menjalankan tugas rumah sakit mempunyai fungsi :

1. Penyelenggaraan pelayanan pengobatan dan pemulihan kesehatan sesuai dengan standar pelayanan rumah sakit

2. Pemeliharaan dan peningkatan kesehatan perorangan melalui pelayanan kesehatan yang paripurna tingkat kedua dan ketiga sesuai kebutuhan medis

3. Penyelenggaraan pendidikan dan pelatihan sumber daya manusia dalam rangka peningkatan kemampuan dalam pemberian pelayanan kesehatan

4. Penyelenggaraan penelitian dan pengembangan serta penapisan teknologi bidang kesehatan dalam rangka peningkatan pelayanan kesehatan dengan memperhatikan etika ilmu pengetahuan bidang kesehatan 
Dalam upaya menyelenggarakan fungsinya, maka rumah sakit umum menyelenggarakan kegiatan :

1. Pelayanan medis

2. Pelayanan dan asuhan keperawatan

3. Pelayanan penunjang medis dan nonmedis

4. Pelayanan kesehatan kemasyarakatan dan rujukan

5. Pendidikan, penelitian dan pengembangan

6. Administrasi umum dan keuangan

\section{Klasifikasi Rumah Sakit}

Rumah sakit dapat diklasifikasikan menjadi beberapa golongan berdasarkan jenis pelayanan, kepemilikan, jangka waktu pelayanan, kapasitas tempat tidur, afiliasi pendidikan, dan status akreditasi. Adapun klasifikasi berdasarkan kepemilikan terdiri atas:

1. Rumah sakit pemerintah terdiri atas:

a. rumah sakit vertikal yang langsung di kelola oleh Departemen Kesehatan

b. rumah sakit pemerintah daerah

c. rumah sakit militer

d. rumah sakit BUMN.

2. Rumah sakit swasta adalah rumah sakit yang dikelola oleh masyarakat.

Sedangkan Rumah Sakit Umum Pemerintah Pusat dan Daerah diklasifikasikan menjadi Rumah Sakit Umum kelas A, B, C, dan D. Klasifikasi tersebut didasarkan pada unsur pelayanan, ketenagaan fisik, dan peralatan.

a. Rumah sakit umum kelas A adalah rumah sakit umum yang mempunyai fasilitas dan kemampuan pelayanan medik spesialistik luas dan subpesialistik luas.

b. Rumah sakit umum kelas B adalah rumah sakit umum yang mempunyai fasilitas dan kemampuan pelayanan medis sekurang-kurangnya 11 spesialistik dan subspesialistik terbatas. 
c. Rumah sakit umum kelas $\mathrm{C}$ adalah rumah sakit umum yang mempunyai fasilitas dan kemampuan pelayanan medik spesialistik dasar.

d. rumah sakit umum kelas $\mathrm{D}$ adalah rumah sakit umum yang mempunyai fasilitas dan kemampuan pelayanan medik dasar (Siregar, 2004).

\section{E. Perawat di Rumah Sakit}

Undang-undang Republik Indonesia Nomor 36 Tahun 2014 tentang Tenaga kesehatan menyatakan bahwa jenis tenaga kesehatan yang termasuk dalam kelompok tenaga keperawatan terdiri dari atas berbagai jenis perawat. Menurut Undangundang Republik Indonesia Nomor 38 Tahun 2014 tentang Keperawatan, pelayanan keperawatan adalah suatu bentuk pelayanan profesional yang merupakan bagian integral dari pelayanan kesehatan yang didasarkan pada ilmu dan kiat Keperawatan ditujukan kepada individu, keluarga, kelompok, atau masyarakat, baik sehat maupun sakit.

Beberapa karakteristik yang harus dimiliki praktik keperawatan (Suroso, 2003) sebagai berikut :

1. Otonomi profesi

2. Tanggung gugat

3. Kemandirian dalam pengambilan keputusan

4. Kolaborasi

5. Advokasi

6. Fasilitasi

7. Standar asuhan dan kode etik profesi keperawatan mencakup 8 standar (jaminan mutu, pendidikan, penilaian kinerja, kesejawatan, etika, kolaborasi, riset dan pemanfaaatan sumber)

Adapun pembagian jenjang karir perawat sesuai syarat dan kompetensi Perawat Klinik (PK) di Indonesia berdasarkan Depkes RI Tahun 2006 adalah sebagai berikut: 
Tabel 2.1 Syarat dan Kompetensi Perawat Klinik

\begin{tabular}{|c|c|c|c|}
\hline No & Level & Syarat & Kompetensi \\
\hline 1 & PK I & $\begin{array}{l}\text { D-III } \\
\text { Keperawatan + } \\
\text { pengalaman } \\
\text { kerja } 2 \text { tahun } \\
\text { S-1 } \\
\text { Keperawatan } \\
\text { /Ners + } \\
\text { pengalaman } \\
\text { kerja } 0 \text { tahun }\end{array}$ & $\begin{array}{l}\text { 1. Memberikan } \\
\text { keperawatan dasar } \\
\text { 2. Memberikan askep } \\
\text { dengan bimbingan dari } \\
\text { perawat klinik lebih } \\
\text { tinggi }\end{array}$ \\
\hline
\end{tabular}

\begin{aligned} & \hline Level Syarat \multicolumn{1}{c}{ Kompetensi } \\ & \hline 3. $\begin{array}{l}\text { Melakukan pendidikan } \\ \text { kesehatan pada klien } \\ \text { dan keluarga }\end{array} \\ &$ 4. $\begin{array}{l}\text { Melakukan } \\ \text { dokumentasi askep } \\ \text { Melakukan kolaborasi } \\ \text { dengan profesi lain }\end{array} \\ &$\hline\end{aligned}

2 PK II D-III

1. Memberikan

Keperawatan + keperawatan dasar pengalaman dalam lingkup

kerja 5 tahun keperawatan: Medikal S-1 bedah/Maternitas/

Keperawatan

/Ners + Pediatrik tanpa komplikasi/tidak pengalaman komplek dengan kerja 3 tahun bimbingan terbatas dari perawat klinik yang lebih tinggi

2. Melakukan tindakan kolaborasi dengan profesi lain. 